\title{
Use of the bronchial blocker via laryngeal mask airway for one-lung ventilation in children undergoing thoracoscopic surgery: a randomized controlled study.
}

\author{
XH Cao ${ }^{1}$, Wangping Zhang $^{2}$, $\mathrm{L} \mathrm{Huang}^{1}$, and ZY Hu${ }^{1}$ \\ ${ }^{1}$ Affiliation not available \\ ${ }^{2}$ Jiaxing Univ
}

September 29, 2020

\begin{abstract}
Aim Tracheal tubes were placed together with bronchial blocker into trachea, which would result in increased airway resistance and hypoventilation in young children. The aim of this study is to investigate the efficacy and safety of laryngeal mask way (LMA) with the bronchial blocker for OLV in children undergoing thoracoscopic surgery. Methods: Sixty children undergoing thoracoscopic surgery were randomly divided into two groups in this prospective, controlled clinical study. The group A received OLV using the bronchial blocker via LMA, while the group B received OLV using the extraluminal technique of the bronchial blocker. The placement time of LMA and the bronchial blocker was noted. Respiratory mechanic parameters [tidal volume (Vt), compliance of lung (CL) and PETCO2] were recorded. Postoperative complications were also recorded. Results: The placement time was shorter in group A than in the group B $(3.9 \pm 0.5$ vs. $5.2 \pm 0.7 \mathrm{~min}, \mathrm{P}<0.01)$. Vt and CL $30 \mathrm{~min}$ after the initiation of OLV were increased in group A than in group B $(97.3 \pm 7.4 \mathrm{vs} 89.9 \pm 7.8 \mathrm{ml}, 23.2 \pm 2.6 \mathrm{vs} 20.3 \pm 3.5 \mathrm{ml} / \mathrm{cmH} 2 \mathrm{O}$, $\mathrm{P}<0.01$, respectively), while PETCO2 in group A were lower compared to the group B $(39.4 \pm 4.3 \mathrm{vs} .43 .5 \pm 4.8 \mathrm{mmHg}, \mathrm{P}=$ 0.01). At $30 \mathrm{~min}$ after the initiation of OLV, $\mathrm{PaO} 2$ was higher in group A (236.6 \pm 41.0 vs $208.2 \pm 45.9 \mathrm{mmHg}, \mathrm{P}=0.014)$, while $\mathrm{PaCO} 2$ were lower in group $\mathrm{A}(43.8 \pm 2.5$ vs $46.3 \pm 4.1 \mathrm{mmHg}, \mathrm{P}=0.006)$, there were statistical significant differences in $\mathrm{PaO} 2$ and $\mathrm{PaCO} 2$ between the 2 groups. Conclusions: Use of the bronchial blocker via LMA for OLV takes less placement time and improves ventilation and with fewer complications compared to the extraluminal technique. It provides a novel approach to lung isolation in pediatric thoracic anesthesia.
\end{abstract}

\section{Hosted file}

LMA-IJCP.pdf available at https://authorea.com/users/363008/articles/483932-use-of-thebronchial-blocker-via-laryngeal-mask-airway-for-one-lung-ventilation-in-childrenundergoing-thoracoscopic-surgery-a-randomized-controlled-study

\section{Hosted file}

Fig 1.pdf available at https://authorea.com/users/363008/articles/483932-use-of-thebronchial-blocker-via-laryngeal-mask-airway-for-one-lung-ventilation-in-childrenundergoing-thoracoscopic-surgery-a-randomized-controlled-study 

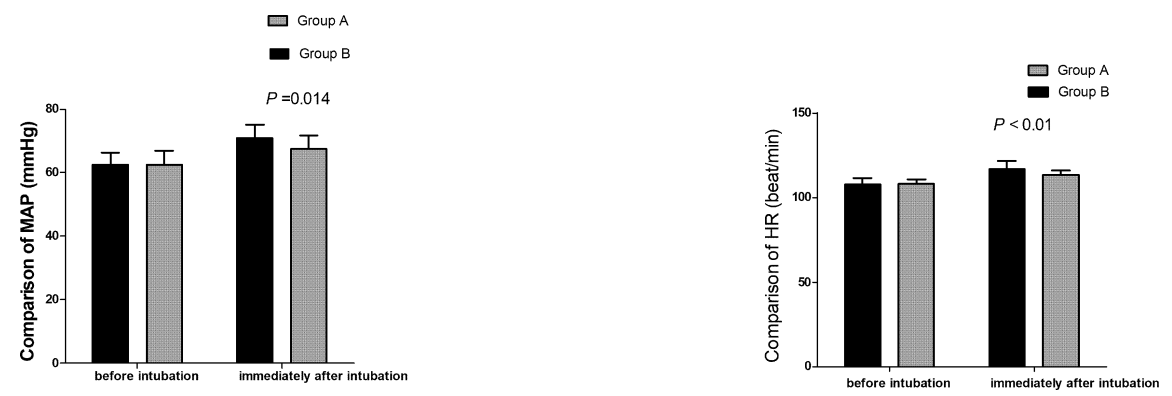
$3 a$

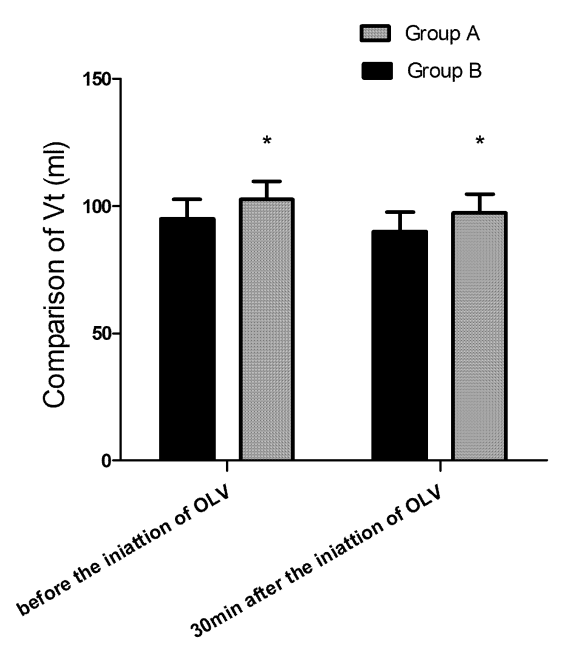

\section{$3 c$}

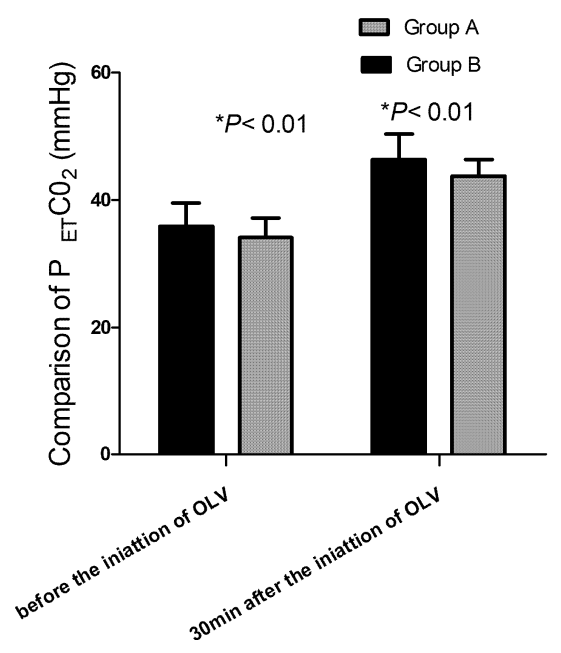

$3 b$

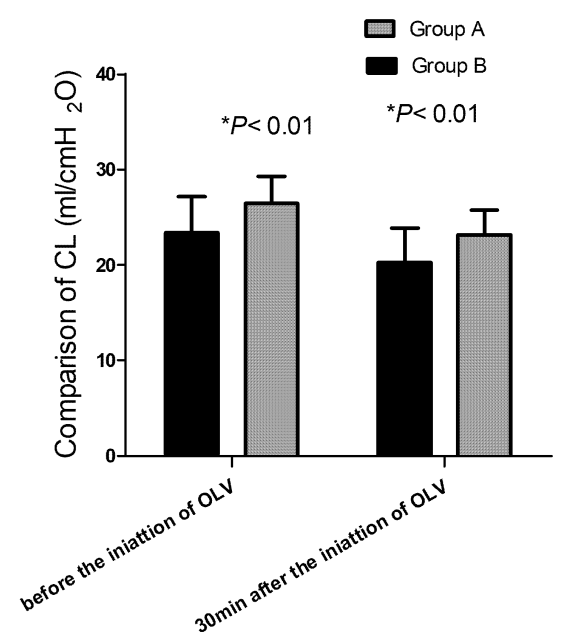

\section{Hosted file}

tab 1.pdf available at https://authorea.com/users/363008/articles/483932-use-of-thebronchial-blocker-via-laryngeal-mask-airway-for-one-lung-ventilation-in-childrenundergoing-thoracoscopic-surgery-a-randomized-controlled-study

Hosted file 
tab 2.pdf available at https://authorea.com/users/363008/articles/483932-use-of-thebronchial-blocker-via-laryngeal-mask-airway-for-one-lung-ventilation-in-childrenundergoing-thoracoscopic-surgery-a-randomized-controlled-study

\section{Hosted file}

tab 3.pdf available at https://authorea.com/users/363008/articles/483932-use-of-thebronchial-blocker-via-laryngeal-mask-airway-for-one-lung-ventilation-in-childrenundergoing-thoracoscopic-surgery-a-randomized-controlled-study 